\title{
Diet of a community of frogs in an agroecosystem in western Cuba
}

\author{
L. Yusnaviel García-Padrón ${ }^{1, *}$ iD \\ 'Sociedad Cubana de Zoología, Pinar del Río, Cuba \\ "Corresponding author (yusnaviel@gmail.com)
}

Edited by: Robert W. Henderson. Date of publication: 11 June 2021.

Citation: García-Padrón LY (2021) Diet of a community of frogs in an agroecosystem in western Cuba. Caribbean Herpetology, 76, 1-8. DOI: https://doi.org/10.31611/ch.76

\begin{abstract}
The study of frog diets in agricultural areas enables us to recognize their role in terrestrial food webs as predators of invertebrates, which can become crop pests or disease transmission vectors for humans. The present study examines the diet composition of three syntopic frog species occurring in one agroecosystem in Cuba, and their interspecific trophic interactions. The fieldwork was in Zea mays and Colocasia esculenta crops in Pinar del Río province, Cuba, in August, 2020. The frogs were measured and stomach-flushed in situ, and released at the site of capture. Niche overlap between species was calculated. Fifty-two frogs were captured and $\mathbf{4 3}$ (82.7\%) had prey in their stomachs. Eleutherodactylus goini had the highest rate of prey/stomach and the broadest diet diversity while Osteopilus septentrionalis had the lowest rate and the narrowest diet diversity. High diet overlap was detected between Eleutherodactylus species. The most consumed prey were Lepidoptera, Hymenoptera, and Blattodea. The diet data suggests that these species could be important biological controls of the invertebrate community in the studied agroecosystems. This indicates a positive impact of these native frogs to the crops by controlling noxious and damaging invertebrates.
\end{abstract}

Keywords: Agriculture; amphibians; feeding; crops; Caribbean island; invertebrate control.

\section{Introduction}

Habitat modification due to land use inevitably leads to a loss of biodiversity at different spatial and temporal scales, and affects most species, but its influence is not equal for all species (Piha 2006; Pineda et al. 2008). Amphibians are vulnerable to habitat change as it affects their reproductive mode, foraging strategy, body size, and diet breadth (Duellman \& Trueb 1986; Suazo-Ortuño et al. 2008). Disturbance in such environments can affect not only amphibians, but also arthropods (Trueba et al. 1999; Prinzing et al. 2007; Battles et al. 2013), and amphibians are potentially vulnerable to changes in the arthropod communities on which they feed (Anderson et al. 1999). In spite of their vulnerability, human agricultural activities may provide important habitat for amphibian reproduction and population persistence (Baker \& Halliday 1999; Knutson et al. 2004). The study of diet in anurans can enable us to recognize their role in terrestrial food webs as predators of invertebrates, which can become crop pests or vectors of disease transmission in agroecosystems (Hirai \& Matsui 1999; Attademo et al. 2005).

Fong (1999) made the first approximation regarding the impact of habitat modification in amphibians inhabiting Cuban agroecosystems. The richness of anuran communities was higher in natural forests compared with coffee and timber forest crops (Fong 1999). Some Cuban anuran species are present in human-altered habitats (Díaz \& Cádiz 2008; Rivalta et al. 2014). Worldwide, many recent investigations have focused on the diet of anuran species, but only a few studies have concentrated on changes in diet pertaining to habitat disturbance (Le et al. 2020). The present study examines the diet composition of three syntopic frog species occurring in one agroecosystem in Cuba, and its interspecific trophic interactions. In addition, I compare this result with previous studies about changes in diet in non-altered areas (forest) versus agroecosystems. 


\section{Materials and Methods}

Study site and Sampling. I conducted the fieldwork in El Moncada, Viñales municipality, Pinar del Río province, Cuba (22.545238 N \& 83.843616 W; 130 m elevation). I surveyed one agroecosystem for two consecutive nights (21:00-23:00 h), on 8-9 August 2020. For each captured frog I measured snout-vent length (SVL) with a caliper to the nearest $0.01 \mathrm{~mm}$ in situ. I stomach-flushed all individuals following Mahan \& Johnson (2007) using two different catheter tubes: 3 mm outer diameter for Eleutherodactylus atkinsi Dunn, 1925 and E. goini Schwartz, 1960, and 5.5 $\mathrm{mm}$ for Osteopilus septentrionalis (Duméril and Bibron, 1841) because of the size difference in SVL. The stomach contents were preserved in vials with $75 \%$ ethanol for further analysis. After being stomach-flushed, each individual was released at the site of capture. In the laboratory we measured the prey length (PL) of each item (only intact items) and used a stereoscope to classify them to order level when possible. In some cases, we identified genus and species.

The study area was $3750 \mathrm{~m}^{2}$, and the crops were composed of corn (Zea mays) (Fig. 1A) (1250 $\mathrm{m}^{2}$ ) and taro (Colocasia esculenta) (Fig. 1B) $\left(2500 \mathrm{~m}^{2}\right)$. Because of the small sample size of frogs, the small agricultural area, and the closeness of the crops, I took both crops as a single agroecosystem.

I calculated the volume of each item using the ellipsoid formula (Magnusson et al. 2003): $\mathrm{V}=4 / 3 \pi$ (length/2) (breadth $/ 2)^{2}$. In addition, I calculated the number of consumed items $(\mathrm{N})$ and its percent $\left(\mathrm{N}_{\%}\right)$; the frequency of occurrence $\left(F\right.$, number of stomachs in which a given prey category was found), and its percent $\left(\mathrm{F}_{\%}\right)$; and the volume (V) and its percent $\left(\mathrm{V}_{\%}\right)$ for each prey category. I calculated the Index of Relative Importance (IRI) for every prey category by IRI $=\left(\mathrm{N}_{\%}+\mathrm{V}_{\%}+\mathrm{F}_{\%}\right) / 3$ (Pianka 1973). We used the Levins' index (B') (Krebs 1989) to calculate the trophic niche breadth: $B^{\prime}=1 / \Sigma \mathrm{Pi}^{2}$. Pi = fraction of items in the food category $i$; for standardization of niche breadth $\left(B_{A}\right)$, we use the Hurlbert (1978) proposal: dividing $B^{\prime}$ by the total number of resource states after correcting for a finite number of resources; range $=0$ (no diversity, exclusive use of a single prey type, specialist) to 1 (highest

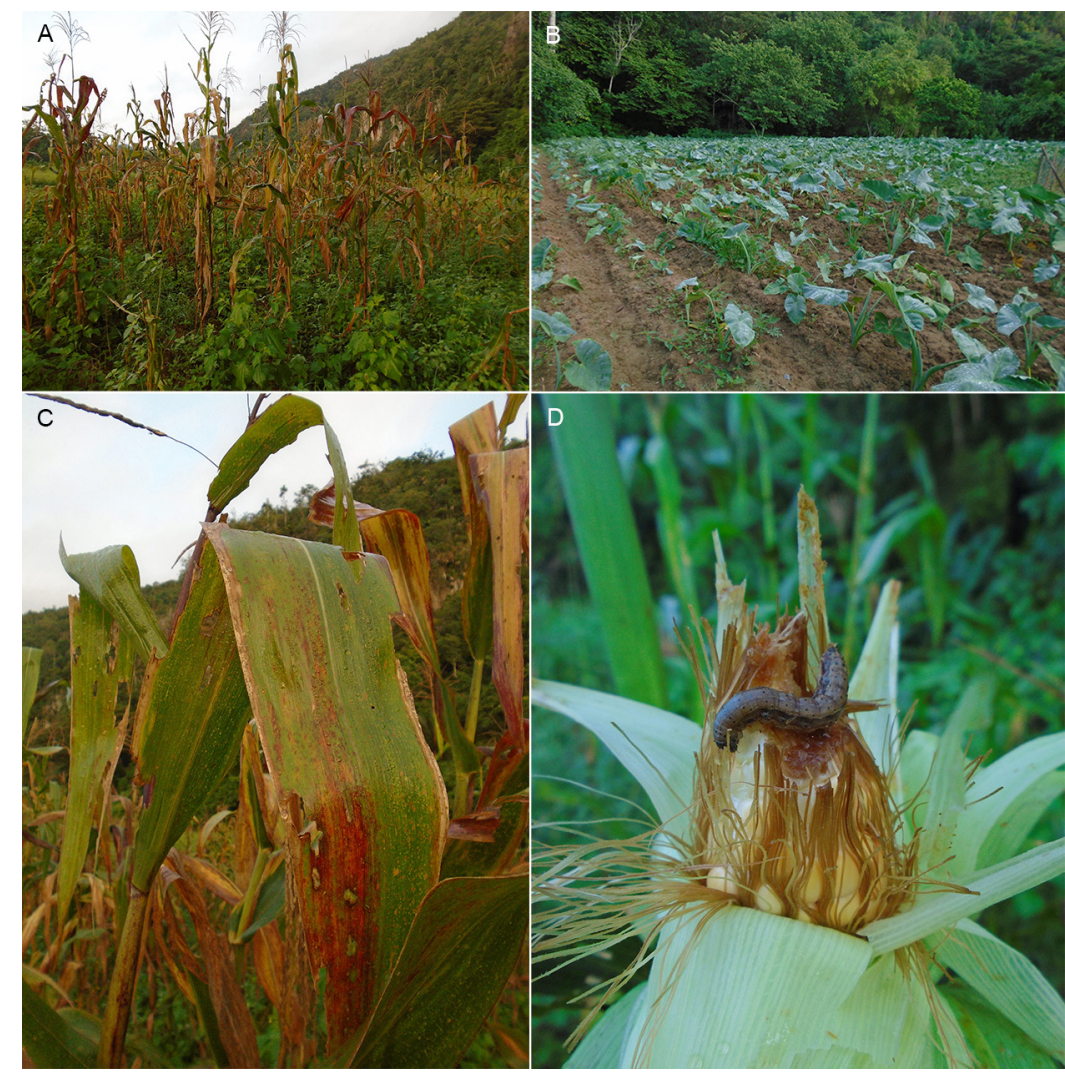

Figure 1. Studied agroecosystems, with (A) Zea mays and (B) Colocasia esculenta crops. (C) Damage in Z. mays leaves. (D) Lepidoptera larvae feeding on a corncob. 
diversity, prey items of all categories, generalist). In addition, we calculated niche overlap between species using Pianka's overlap index (POI hereafter) (Pianka 1973), which varies from 0 (no overlap) to 1 (complete overlap).

Statistical analysis. We applied a normality test (Shapiro-Wilk) to see if the data were normally distributed. Since the data were not normally distributed, I conducted the Mann-Whitney U-test for comparison of SVL among species, and SVL/PL, and SVL/number of prey, and volume of prey consumed between species. I conducted a Spearman correlation coefficient and a simple linear regression to test the correlations and tendencies of SVL/PL, and SVL/number of prey consumed between species. For all tests $P>0.05$.

\section{Results}

I sampled 52 frogs: 12 Eleutherodactylus atkinsi, with 19.2-34.7 mm SVL (26.6 \pm 2.59 , mean \pm SD), 13 E. goini, with 20.7-33.3 mm SVL (25.0 \pm 9.14, mean \pm SD), and 27 Osteopilus septentrionalis, 26.8-108.7 mm SVL (77.0 \pm 35.89 , mean \pm SD). Eleutherodactylus atkinsi and E. goini had similar SVL (U-test $=39.000, P=0.158$ ), but statistically significant differences were observed between the two Eleutherodactylus and O. septentrionalis in SVL (U-test $=6.500$, $P=0.000)$.

Diet. Forty-three frogs had prey in their stomachs (82.7\%), and only nine individuals had empty stomachs (17.3\%) (Table 1). In this study, larger frogs tended to consume larger prey $\left(R^{2}=0.476\right.$; Spearman, 0.477). Eleutherodactylus atkinsi and E. goini consumed prey with similar length (U-test $=39.000, \mathrm{P}=0.158$ ), but both Eleutherodactylus consumed significantly smaller prey than $\mathrm{O}$. septentrionalis (U-test $=31.000, \mathrm{P}=0.000$ ). All three frogs combined consumed 192 invertebrates of 30 taxa (total rate of 4.5 prey/stomach), with a total volume of $5064 \mathrm{~mm}^{3}$. Large frogs consumed fewer prey $\left(\mathrm{R}^{2}=0.38\right.$; Spearman, -0.75$)$. Eleutherodactylus atkinsi and E. goini consumed a similar amount of prey items (U-test $=42.50, \mathrm{P}=0.235$ ), but $\mathrm{O}$. septentrionalis consumed significantly lower numbers of prey than both Eleutherodactylus (U-test $=29.000, \mathrm{P}=0.000$ ). Differences were observed in the volume of prey consumed between Eleutherodactylus and $\mathrm{O}$. septentrionalis ( $\mathrm{U}$-test $=50.000, \mathrm{P}=0.000$ ), and similarities occurred between both Eleutherodactylus (U-test $=117.0, \mathrm{P}=0.271$ ). Eleutherodactylus atkinsi consumed $5.64 \mathrm{prey} / \mathrm{stomach}$, with a volume of $115.42 \mathrm{~mm}^{3}$; E. goini had the highest prey consumption rate (7.83 prey/stomach), and the lowest volume $\left(112.36 \mathrm{~mm}^{3}\right)$. Osteopilus septentrionalis had the lowest rate of consumption (1.8 prey/stomach) but the highest volume $\left(4836 \mathrm{~mm}^{3}\right.$ ) (Table 1$)$.

Eleutherodactylus atkinsi ate mostly Hymenoptera (Formicidae), Isopoda, Coleoptera, and Aranae; E. goini ate Hymenoptera (Formicidae), Lepidoptera larvae (Fig. 1D), and Aranae (Table 1). The most consumed prey by $O$. septentrionalis were Lepidoptera larvae and Blattodea (Table 1). Large amounts of the invasive fire ant (Wasmannia auropunctata) were observed in the stomachs of the Eleutherodactylus frogs. In one E. goini, a piece of inorganic material (a nylon thread) was observed.

Niche overlap and Niche breadth. Eleutherodactylus goini had the broadest diet of the studied species $(B A=0.37)$, with a richness of 20 prey taxa consumed, followed by E. atkinsi $(B A=0.27 ; 15$ prey taxa); while O. septentrionalis exhibited the narrowest diet $(B A=0.17 ; 14$ prey taxa) (Table 1). I detected an overlap in diet consumption between Eleutherodactylus species ( $\mathrm{POI}=0.70$ ), where both consumed similar amounts of Hymenoptera (Formicidae), Aranae, Isoptera, and Lepidoptera larvae (Table 1). Meanwhile, E. goini and O. septentrionalis overlapped in Lepidoptera larvae, Isoptera, and Blattodea $(\mathrm{POI}=0.50$, Table 1). I observed less overlap among $E$. atkinsi and $O$. septentrionalis $(\mathrm{POI}=0.34)$, due to the differential consumption of Lepidoptera larvae and Isoptera, respectively (Table 1).

\section{Discussion}

Anurans are known to prey on noxious arthropods (Okada 1938) and they play an important role in controlling pest insects (Okada 1938; Attademo et al. 2005). Here l examine anuran diet in agroecosystems from Cuba. Despite the fact that the results presented here may be biased because the small sample size, this approach establishes a baseline to extend the study on the diet of Cuban amphibians in agroecosystems. This study contributes to the 
Table 1. Diet composition of Eleutherodactylus atkinsi, E. goini, and O. septentrionalis in the study area.

\begin{tabular}{|c|c|c|c|c|c|c|c|c|c|c|c|c|c|}
\hline \multirow[t]{2}{*}{ Classes } & \multirow[t]{2}{*}{ Orders } & \multicolumn{4}{|c|}{ Eleutherodactylus atkinsi $(N=11)$} & \multicolumn{4}{|c|}{ Eleutherodactylus goini $(N=12)$} & \multicolumn{4}{|c|}{ Osteopilus septentrionalis $(N=20)$} \\
\hline & & $\mathrm{F}(\%)$ & $\mathrm{N}(\%)$ & $\mathrm{V}(\%)$ & $\mid \mathrm{RI}(\%)$ & $F(\%)$ & $\mathrm{N}(\%)$ & $\mathrm{V}(\%)$ & IRI (\%) & $F(\%)$ & $\mathrm{N}(\%)$ & $\mathrm{V}(\%)$ & IRI (\% \\
\hline \multirow[t]{2}{*}{ Diplopoda } & Polydesmida & 0 & 0 & 0 & 0 & $2(4.00)$ & $2(2.13)$ & $11.29(10.1)$ & 5.39 & 0 & 0 & 0 & 0 \\
\hline & Spirobolida & 0 & 0 & 0 & 0 & $2(4.00)$ & $2(2.13)$ & $2.18(1.94)$ & 2.69 & 0 & 0 & 0 & 0 \\
\hline Chilopoda & Scolopendromorpha & 0 & 0 & 0 & 0 & $2(4.00)$ & $2(2.13)$ & $0.66(0.59)$ & 3.84 & $1(3.33)$ & $1(2.78)$ & $400(8.26)$ & 4.79 \\
\hline \multirow[t]{4}{*}{ Arachnida } & Aranae & $5(11.6)$ & $8(12.9)$ & $5.7(4.94)$ & 9.82 & $5(10.0)$ & $6(6.38)$ & $1.29(1.15)$ & 5.84 & $1(3.33)$ & $1(2.78)$ & $3.39(0.07)$ & 2.06 \\
\hline & Opiliones & 0 & 0 & 0 & 0 & $2(4.00)$ & $2(2.13)$ & $0.04(0.04)$ & 2.06 & 0 & 0 & 0 & 0 \\
\hline & Acari & & & & & & & & & & & & \\
\hline & Mesostigmata & $3(6.98)$ & $3(4.84)$ & $0.19(0.16)$ & 3.99 & $1(2.00)$ & $1(1.06)$ & $0.21(0.19)$ & 1.08 & 0 & 0 & 0 & 0 \\
\hline \multirow[t]{23}{*}{ Hexapoda } & Orthoptera & $5(11.6)$ & $5(8.06)$ & $7.2(6.24)$ & 8.64 & 0 & 0 & 0 & 0 & $1(3.33)$ & $1(2.78)$ & $114(2.37)$ & 2.83 \\
\hline & $\begin{array}{l}\text { Hymenoptera (Formi- } \\
\text { cidae) }\end{array}$ & $4(9.30)$ & $10(16.1)$ & $1.1(0.95)$ & 8.79 & $5(10.0)$ & $29(30.9)$ & $2.52(2.24)$ & 14.4 & $1(3.33)$ & $1(2.78)$ & $5.17(0.11)$ & 2.07 \\
\hline & Wasmannia auropunctata & 7 (16.3) & $10(16.1)$ & $0.29(0.25)$ & 10.9 & $5(10.0)$ & $18(19.2)$ & $0.80(0.71)$ & 9.95 & 0 & 0 & 0 & 0 \\
\hline & Diptera & 0 & 0 & 0 & 0 & $1(2.00)$ & $1(1.06)$ & $0.20(0.18)$ & 1.08 & $1(3.33)$ & $1(2.78)$ & $4.36(0.09)$ & 2.07 \\
\hline & Cucilidae & $2(4.65)$ & $2(3.23)$ & $5.48(4.75)$ & 4.21 & 0 & 0 & 0 & 0 & 0 & 0 & 0 & 0 \\
\hline & larvae & $1(2.33)$ & $2(3.23)$ & $0.97(0.84)$ & 2.13 & $2(4.00)$ & $2(2.13)$ & $14.2(12.6)$ & 6.24 & 0 & 0 & 0 & 0 \\
\hline & Lepidoptera & $1(2.33)$ & $1(1.61)$ & $6.32(5.48)$ & 3.14 & 0 & 0 & 0 & 0 & $4(13.3)$ & $5(13.89)$ & $28.7(0.59)$ & 9.27 \\
\hline & larvae & $3(6.98)$ & $4(6.45)$ & $17.4(15.1)$ & 9.5 & $5(10.0)$ & $6(6.38)$ & $36.2(32.2)$ & 16.2 & $9(30.0)$ & $10(27.78)$ & $145(3.01)$ & 20.3 \\
\hline & Blattodea & 0 & 0 & 0 & 0 & $3(6.00)$ & $3(3.19)$ & $20.5(18.2)$ & 9.13 & $3(10)$ & $4(11.11)$ & $888(18.4)$ & 13.2 \\
\hline & Periplaneta americana & 0 & 0 & 0 & 0 & 0 & 0 & 0 & 0 & $2(6.67)$ & $2(5.56)$ & $2113(43.7)$ & 18.7 \\
\hline & Coleoptera & & & & & & & & & & & & \\
\hline & Anobiidae & 0 & 0 & 0 & 0 & $1(2.00)$ & $1(1.06)$ & $0.22(0.20)$ & 1.09 & 0 & 0 & 0 & 0 \\
\hline & Carabidae & 0 & 0 & 0 & 0 & $1(2.00)$ & $1(1.06)$ & $9.96(8.86)$ & 3.97 & 0 & 0 & 0 & 0 \\
\hline & Chrysomelidae & $1(2.33)$ & $1(1.61)$ & $37.6(32.6)$ & 12.18 & 0 & 0 & 0 & 0 & 0 & 0 & 0 & 0 \\
\hline & Curculionidae & 0 & 0 & 0 & 0 & $1(2.00)$ & $1(1.06)$ & $0.93(0.83)$ & 1.30 & 0 & 0 & 0 & 0 \\
\hline & Passalidae & $4(9.30)$ & $4(6.45)$ & $6.68(5.79)$ & 7.18 & 0 & 0 & 0 & 0 & 0 & 0 & 0 & 0 \\
\hline & Staphylinidae & 0 & 0 & 0 & 0 & $1(2.00)$ & $1(1.06)$ & $0.27(0.24)$ & 1.10 & 0 & 0 & 0 & 0 \\
\hline & Protrura & 0 & 0 & 0 & 0 & $3(6.00)$ & $3(3.19)$ & $1.35(1.20)$ & 3.46 & 0 & 0 & 0 & 0 \\
\hline & Hemiptera & 0 & 0 & 0 & 0 & 0 & 0 & 0 & 0 & $1(3.33)$ & $1(2.78)$ & $8.56(0.18)$ & 2.10 \\
\hline & Fulgoridae & $1(2.33)$ & $1(1.61)$ & $1.49(1.29)$ & 1.74 & $2(4.00)$ & $3(3.19)$ & $3.52(3.13)$ & 3.44 & $1(3.33)$ & $1(2.78)$ & $4.91(0.10)$ & 2.07 \\
\hline & Heteroptera & & & & & & & & & & & & \\
\hline & Cydnidae & $1(2.33)$ & $1(1.61)$ & 14.6 (12.6) & 5.52 & 0 & 0 & 0 & 0 & 0 & 0 & 0 & 0 \\
\hline & Collembola & $1(2.33)$ & $1(1.61)$ & $0.1(0.09)$ & 1.34 & $1(2.00)$ & $1(1.06)$ & $0.11(0.10)$ & 1.05 & 0 & 0 & 0 & 0 \\
\hline \multicolumn{14}{|c|}{ Gastropoda Systellommatophora } \\
\hline & Leidyula sp. & 0 & 0 & 0 & 0 & 0 & 0 & 0 & 0 & $2(6.67)$ & $4(11.11)$ & 799 (16.51) & 11.4 \\
\hline & Stylommatophora & & & & & & & & & & & & \\
\hline & Polygyridae & & & & & & & & & & & & \\
\hline & Praticolella griseola & 0 & 0 & 0 & 0 & 0 & 0 & 0 & 0 & $2(6.67)$ & $2(5.56)$ & $299(6.19)$ & 6.14 \\
\hline Crustacea & Isopoda & $4(9.30)$ & $9(14.5)$ & $10.3(8.96)$ & 10.93 & $5(10.0)$ & $9(9.57)$ & $6.05(5.38)$ & 8.32 & $1(3.33)$ & $2(5.56)$ & $23.0(0.47)$ & 2.12 \\
\hline \multicolumn{2}{|c|}{ Inorganic Material } & 0 & 0 & 0 & 0 & 1 & 1 & 0 & 0 & 0 & 0 & 0 & 0 \\
\hline \multirow{2}{*}{\multicolumn{2}{|c|}{ Vegetal material }} & 0 & 0 & 0 & 0 & 1 & 1 & 0 & 0 & 1 & 1 & 0 & 0 \\
\hline & & 0 & 0 & 0 & 0 & 1 & 1 & 0 & 0 & 1 & 1 & 0 & 0 \\
\hline
\end{tabular}

knowledge of the ecological role of this group as it relates to the economics and social development of this country.

A weak relationship between SVL and prey length is known for some Eleutherodactylus frogs in the West Indies (Woolbright \& Stewart 1987; Ovaska 1991; Joglar 1998), and consequently for Cuban species (García-Padrón \& Borrego 2020; García-Padrón et al. 2021). I obtained similar results in this study, but larger frogs tend to consume larger prey, especially Osteopilus septentrionalis, than the studied Eleutherodactylus. The number of prey per stomach was negatively correlated with SVL. Eleutherodactylus atkinsi and E. goini tend to consume more prey items than $O$. septentrionalis; nonetheless, this hylid had a higher volume of prey than the two Eleutherodactylus combined.

Some arthropods, such as Orthoptera, Lepidoptera, Coleoptera, and Hemiptera, have been recognized as "direct damagers" of plants, because they directly feed or oviposit on them, or act as vectors of pathogens (Gillott 2005; this study, Fig. 1C, 1D). In this study, the most consumed prey were Lepidoptera (both adults and larvae), followed by Hymenoptera (Formicidae), and Blattodea. Differences in type of prey, prey size, and the amount of prey consumed could be ecological responses to avoid trophic overlap in syntopic species (Werner et al. 1995). A nylon thread was observed in one E. goini, probably consumed accidently. Unfortunately, trash deposits are common in the study area, due to such human activities such as agriculture, and raising cattle and chickens, and this could cause injury or even death to these frogs. The variety of invertebrates consumed by the studied species may 
suggest that they could potentially be an important biological control factor of the invertebrate community in the studied agroecosystems, but longer scale studies are recommended to demonstrate this hypothesis. A prey per stomach rate (4.5 prey/individual), the total amount of prey consumed (192 items), and the high volume of prey consumed $\left(5064 \mathrm{~mm}^{3}\right)$ may suggest a positive impact of these native frogs to the agroecosystems, as well as to human health and economy (by controlling noxious and damaging invertebrates), despite the small sample size (Fig. 1C, 1D).

I detected invasive species in stomach contents, which represented a volumetrically important part in the diet of the three frogs studied. Eleutherodactylus consumed a large number of the invasive fire ant (W. auropunta$t a)$, and $O$. septentrionalis consumed many roaches, especially $P$. americana, which are both plagues in Cuba. The land slug Leidyula sp., and the introduced and invasive snail Praticolella griseola, may directly affect agroecosystems in urban and rural areas in Cuba (Vázquez et al. 2005; Espinosa \& Ortea 2009; Matamoros 2014). Osteopilus septentrionalis consumed largely these species of mollusks in the study area, and were represented in $13 \%$ of its stomach samples (see Table 1).

Previous studies demonstrate that habitat modification for crops is less favorable to amphibians than un-modified forested areas (Fong 1999; Ray et al. 2002). García-Padrón \& Borrego (2020) examined the diet composition of E. atkinsi in forested areas and they observed more diversity and abundance of prey consumed (numerically and volumetrically; García-Padrón \& Borrego 2020) than in the present study. This species had a preference for formicids, isopods, spiders, and at a lower rate, crickets (García-Padrón \& Borrego 2020). A low prevalence of Lepidoptera was observed in forested areas (García-Padrón \& Borrego 2020); however, I observed a high rate of consumption in agroecosystems, mostly at the larva stage, which is harmful to crops (Gillott 2005; this study, Fig. 1C, 1D). Eleutherodactylus atkinsi consumed similar prey categories in the forest and in agroecosystems (García-Padrón \& Borrego 2020; this study); this may suggest that this frog has a relatively narrow trophic niche and a high specialization on those types of prey. Osteopilus septentrionalis is a generalist predator and a strong competitor that consumes larger prey than other syntopic amphibians, with a high preference for beetles (Meshaka 2001; Owen 2005; Glorioso et al. 2012). Glorioso et al. (2012) evaluated the diet composition of O. septentrionalis in forested situations in Florida, and they observed a large consumption of coleopterans, roaches, orthopterans, spiders, formicids and lepidopteran larvae. Similar results (in diversity and number of prey consumed) were obtained in the present study despite smaller sample sizes, which corroborates the enormous trophic plasticity of this frog. On the other hand, no other contribution regarding the diet of E. goini has been made in Cuba, therefore this contribution is the first approach to the diet of this species. Disturbance of habitats can affect amphibians and their arthropod prey and thus affect resource uptake (Trueba et al. 1999; Prinzing et al. 2007; Battles et al. 2013). This could be a plausible hypothesis to the lesser diversity of suitable prey consumed by the studied species in this agroecosystems when compared with forests, but further studies are encouraged.

The reduction or absence of frogs is inversely proportional to the abundance of certain arthropods (Beard et al. 2003; Luría-Manzano \& Ramirez-Bautista 2019). Therefore, the reduction of anuran communities in agroecosystems may have negative consequences for crops, and consequently the local and/or regional economy, by increasing the harmful arthropod plague in those areas. Additional studies about temporal variation (e.g. richness, abundance, crop damage evaluation, etc.) of invertebrate communities during the growing season and after harvest and the impact of anurans on this invertebrate community in the studied agroecosystem, are necessary. Native anurans may be important in controlling arthropod pests in agroecosystems while avoiding the negative side effects of pesticides (Attademo et al. 2005, 2007). In addition, many vertebrates (e.g. mammals, birds, fishes, amphibians, and reptiles) are known as regulators of insect populations (Gullan \& Cranston 2014). The combined action of several native biological control agents, vertebrates and insect-consuming invertebrates, could have a positive influence on agroecosystems by controlling and/or eradicating the phytophagous insects that negatively impact crops. 


\section{Acknowledgements}

I thank the staff of the Centro Nacional de Entrenamiento Espeleológico "Antonio Núñez Jiménez", and the director and staff of the Viñales National Park, for their hospitality and logistical help; María Matilde Delgado Albizar and Kenay Gómez Carmenate for their assistance during the fieldwork, Lic. Jerson M. Rodríguez García for invaluable help during laboratory analysis; and Javier Torres, Tom Kinsky and the anonymous reviewers for their suggestions on an earlier draft of this manuscript.

\section{References}

Anderson AM, Haukos DA, \& Anderson JT (1999) Diet composition of three anurans from the Playa wetlands of northwest Texas. Copeia, 1999, 515-520. https://doi.org/10.2307/1447502

Attademo A, Peltzer PM, \& Lajmanovich RC (2005) Amphibians occurring in soybean and implications for biological control in Argentina. Agriculture, Ecosystems and Environment, 106, 389-394. https://doi.org/10.1016/j. agee.2004.08.012

Attademo A, Peltzer PM, \& Lajmanovich RC (2007) Feeding habits of Physalaemus biligonigerus (Anura, Leptodactylidae) from soybean field of Córdoba province, Argentina. Russian Journal of Herpetology, 14(1), 1-6.

Baker JM, \& Halliday TR (1999) Amphibian colonization of new ponds in an agricultural landscape. Herpetological Journal, 9, 55-63.

Battles AC, Whittle TK, Stehle CM, \& Johnson MA (2013) Effects of human land use on prey availability and body condition in the Green Anole Lizard, Anolis carolinensis. Herpetological Conservation and Biology, 8, 16-26.

Beard KH, Eschtruth AK, Vogt KA, Vogt DJ, \& Scatena FN (2003) The effects of the frog Eleutherodactylus coqui on invertebrates and ecosystem processes at two scales in the Luquillo Experimental Forest, Puerto Rico. Journal of Tropical Ecology, 19, 607-617. https://doi.org/10.1017/S0266467403006011

Díaz LM, \& Cádiz A (2008) Guía taxonómica de los anfibios de Cuba. AbcTaxa, 4, 1-294.

Duellman WE, \& Trueb L (1986) Biology of Amphibians. McGraw-Hill, Baltimore, USA, 670 pp.

Espinosa J, \& Ortea J (2009): Los moluscos terrestres de Cuba. Espartacus-Sociedad de Zoología de Cuba. UPC Print, Vaasa, Finlandia, 191 pp.

Fong A (1999) Changes in amphibian composition in altered habitats of Eastern Cuba. Froglog, 36, 2-3.

García-Padrón LY, \& Borrego C (2020) Dieta de Eleutherodactylus atkinsi (Anura: Eleutherodactylidae) en el occidente de Cuba. Poeyana, 511, 53-58.

García-Padrón LY, Boligán M, \& Barrero Medel H (2021) Diet of the Cuban giant frog, Eleutherodactylus zeus (Anura: Eleutherodactylidae) in Viñales National Park, Cuba. Cuadernos de Herpetología, 35(1), 43-51. https://doi. org/10.31017/CdH.2021.(2020-035)

Gillott C (2005) Entomology. Third Edition. Springer Science and Business Media, Dordrecht, The Netherlands, 831 pp. https://doi.org/10.1007/1-4020-3183-1

Glorioso BM, Waddle JH, Crockett ME, Rice KG, \& Percival HF (2012) Diet of the invasive Cuban Treefrog (Osteopilus septentrionalis) in pine rockland and mangrove habitats in South Florida. Caribbean Journal of Science, 46(2-3), 346-355. https://doi.org/10.18475/cjos.v46i2.a25

Gullan PJ, \& Cranston PS (2014) The insects: An outline of entomology. Fifth Edition. John Wiley \& Sons, UK, 595 pp. +8 plates.

Hirai T, \& Matsui M (1999) Feeding habits of the pond frog, Rana nigromaculata, inhabiting rice fields in Kyoto, Japan. Copeia, 1999, 940-947. https://doi.org/10.2307/1447969

Hurlbert HS (1978) The measurement of niche overlap and some relatives. Ecology, 59, 67-77. https://doi. org/10.2307/1936632

Joglar RL (1998) Los coquíes de Puerto Rico, su historia natural y su conservación. Editorial de la Universidad de Puerto Rico, 232 pp. 
Knutson MG, Richardson WB, Reineke DM, Gray BR, Parmelee, J.R., \& Weick, S.E. (2004) Agricultural ponds support amphibian populations. Ecological Applications, 14, 669-684. https://doi.org/10.1890/02-5305

Krebs CJ (1989) Ecological Methodology. 2nd Edition. Addison-Wesley Educational Publishers, Inc. Menlo Park, CA, $620 \mathrm{pp}$.

Le DTT, Rowley JJL, Tran DTA, \& Hoang HD (2020) The diet of a forest-dependent frog species, Odorrana morafkai (Anura: Ranidae), in relation to habitat disturbance. Amphibia-Reptilia, 41(1), 29-41. https://doi. org/10.1163/15685381-20191171

Luría-Manzano R, \& Ramírez-Bautista A (2019) Dietary composition and selection in the stream-breeding anuran assemblage from a tropical wet forest in eastern Mexico. Acta Oecologica, 98, 36-44. https://doi. org/10.1016/j.actao.2019.06.003

Magnusson WE, Lima AP, Silva WA, \& Araújo MC (2003) Use of geometric forms to estimate volume of invertebrates in ecological studies of dietary overlap. Copeia, 2003, 13-19. http://doi.org/10.1643/0045-8511(2003)003 [0013:UOGFTE]2.0.CO;2

Mahan RD, \& Johnson JR (2007) Diet of the Gray Treefrog (Hyla versicolor) in relation to foraging site location. Journal of Herpetolology, 41, 16-23. https://doi.org/10.1670/0022-1511(2007)41[16:DOTGTH]2.0.CO;2

Matamoros M (2014) Los moluscos fitófagos en la agricultura cubana. Agricultura Orgánica, 2, 9-13.

Meshaka WE Jr. (2001) The Cuban treefrog in florida: life history of a successful colonizing species. Gainesville, University Press of Florida, Florida, USA, 191 pp.

Okada Y (1938) The ecological studies of the frogs with special reference to their feeding habits. Journal of the Imperial Agriculture Experimental Station, 3, 275-347.

Ovaska K (1991) Diet of the frog Eleutherodactylus johnstonei (Leptodactylidae) in Barbados, West Indies. Journal of Herpetology, 25(4), 486-488. https://doi.org/10.2307/1564775

Owen JL (2005) The Cuban Treefrog (Osteopilus septentrionalis): Distribution, diet, and reproduction of an invasive species in the British Virgin Islands. MSc. thesis. Texas Tech University, Lubbock.

Pianka ER (1973) The structure of lizard communities. Annual Review of Ecology and Systematics, 4, 53-74. https:// doi.org/10.1146/annurev.es.04.110173.000413

Piha H (2006) Impacts of agriculture on amphibians at multiple scales. Doctoral dissertation. University of Helsinki, Faculty of Bioscience, Finland.

Pineda E, Moreno C, Escobar F, \& Halfter G (2008) Frog, Bat, and Dung Beetle Diversity in the Cloud Forest and Coffee Agroecosystems of Veracruz, Mexico. Conservation Biology, 19, 400-410. http://doi.org/10.1111/j.15231739.2005.00531.x

Prinzing A, Dauber J, Hammer E, Hammouti N, \& Böhning-Gaese K (2007) Perturbed partners: opposite responses of plant and animal mutualism guilds to inundation disturbances. Oikos, 116(8), 1299-1310. http://doi. org/10.1111/j.2007.0030-1299.15738.x

Ray N, Lehmann A, \& Joly P (2002) Modeling spatial distribution of amphibian populations: a GIS approach based on habitat matrix permeability. Biodiversity Conservation, 11, 2143-2165. https://doi. org/10.1023/A:1021390527698

Rivalta González V, Rodríguez-Schettino L, Mancina CA, \& Iturriaga M (2014) Amphibians of Cuba: checklist and geographic distribution. Smithsonian Herpetological Information Service, 145, 1-50. http://doi.org/10.5479/ si.23317515.145.1 
Suazo-Ortuño I, Alvarado-Díaz J, \& Martínez-Ramos M (2008) Effects of Conversion of Dry Tropical Forest to agricultural Mosaic on Herpetofaunal Assemblages. Conservation Biology, 22, 362-374. https://doi.org/10.1111/ j.1523-1739.2008.00883.x

Trueba DP, Vázquez González MM, \& Rodríguez Aragonés C (1999) Comunidades de la mesofauna edáfica en una selva baja inundable de la Reserva de la Biósfera de Sian Kaan, Quintana Roo, México. Revista de Biolología Tropical, 47, 489-492.

Vázquez Moreno LL, Fernández Gonzálvez E, Lauzardo Rico J, García Torriente T, Alfonso Simonetti J, \& Ramírez Ochoa R (2005) Manejo agroecológico de plagas en fincas de la agricultura urbana (MAPFAU). La Habana, Cuba, $54 \mathrm{pp}$.

Werner EE, Wellborn GA, \& McPeek MA (1995) Diet composition in postmetamorphic bullfrogs and green frogs: Implications for interspecific predation and competition. Journal of Herpetology, 29(4), 600-607. https:// doi.org/10.2307/1564744

Woolbright LL, \& Stewart MM (1987) Foraging success of the tropical frog, Eleutherodactylus coqui: the cost of calling. Copeia, 1987(1), 69-75. https://doi.org/10.2307/1446039 